\title{
SILVIA CAPÍKOVÁ,
}

Comenius University in Bratislava,

Faculty of Medicine, Slovak Republic

https://orcid.org/0000-0002-8047-7321

\section{MÁRIA NOVÁKOVÁ,}

Comenius University in Bratislava,

Faculty of Law, Slovak Republic

https://orcid.org/0000-0002-1042-6318

\section{Challenging COVID-19 times - Possibilities and limitations of law in regulation of health behavior of individuals}

Abstract: The paper focuses on the social assumptions of effectiveness and legitimacy of law and its current threats, which became more pronounced during the COVID-19 pandemic. The right to health is a fundamental human right. The protection of population health is one of the tasks and obligations of the state, arising from several international treaties. Law is currently one of the important regulatory mechanisms for the conduct of natural and legal persons. It is one of the important public health instruments that regulates activities that are or may be dangerous to human health, but also to control health behaviour, for example indirectly by taxing cigarettes or directly - by banning the sale of alcoholic beverages to minors. COVID-19 has caused a global pandemic with many casualties. Due to the mode of transmission and the high level of contagion, many countries have taken strict and unpopular restrictive measures that interfere with other human rights, in an effort to reduce mortality. COVID-19 appeared in Slovakia in social conditions, which according to current research are characterized by low trust in the judicial and legal system and state institutions, not a negligible degree 
of anomie and the tendency of the population to share and adopt conspiracy theories. Exercise of the right to freedom of opinion and expression together with informatization of society enables not only the effective dissemination of quality and professional information from experts and public bodies, but also health disinformation or hoaxes about the COVID-19 disease, which undermines the legitimacy of the adopted legislative measures and can play a negative role in efforts to protect right to health.

Keywords: COVID-19, health behavior, health law, public health, disinformation, human rights

\section{Introduction}

Public health law belongs to central elements of modern public health. ${ }^{1}$ According to Reynolds, law and legislation has shaped and can shape the built and social environment that affects public health. This includes the creation of a set of constitutional rights to health and the impact of human rights on public health practice; land use planning; the state of the environment more generally, including the crucial issues of environmental sustainability, where public health laws can adopt novel approaches; and the regulation of communicable and no communicable diseases. ${ }^{2}$

A new, highly contagious virus COVID-19 with severe health and mortality outcomes within few months caused a global pandemic. On the global level, there exist International Sanitary Conventions - a regulation on the level of international

1 J. M. Mann, Medicine and Public Health, Ethics and Human Rights. In: Hastings Center Report, 27, pp. 6-13. (accessed 10 Jun 2020) available from: doi:10.2307/3528660.

2 C. Reynolds, Legal Issues in Public Health. In International Encyclopedia of Public Health, Academic Press, 2008, Pages 45-56, ISBN 9780123739605, https:// doi.org/10.1016/B978-012373960-5.00128-3. 
law, adopted by the World Health Organization. However, a need for specific legal regulation to protect public health and general welfare on national level became urgent. To protect people within national jurisdictions, many countries sooner or later after national outbreak of epidemics adopted restrictive measures by means of national legislation (so called "leges coronae"), in certain extent limiting some of human rights (right to privacy, right to free movement, etc.), but within more or less accurately defined timeline depending on the unpredictable epidemiological situation.

However, protection of the right to health is closely related to the right to life and represents a positive obligation of the state, differs from the right to health care, and also includes preventive measures that are focusing population and favorizing population health instead of the free choice of an individual about how he or she prefers to protects his/her health by his/her individual health behavior. If a health of population is at stake, individuals are supposed to comply with enacted public health measures, such as vaccination programs etc. In Slovakia, right to health is warranted not just by international treaties or conventions, by also by national legislation. The Constitution of the Slovak Republic in its article 40 states: "Everyone shall have the right to protection of his or her health. The citizens shall have the right to free health care and medical equipment for disabilities on the basis of medical insurance under the terms to be laid down by a law." Protection of right to health is in particular enacted by the Act No 355 of 2007 of Collection of Laws of the Slovak Republic (hereinafter as "coll.") "Act on Protection, Support and Development of Public Health", as amended. The interpretation of the Art. 40 by the Constitutional Court highlights that definition of the limits (extent) of the right 
to health cannot be shifted from the legislators to the bodies which belong to the executive power. ${ }^{3}$

Most legislative measures as response to COVID-19 threat, adopted worldwide, were focusing to change health behaviour of individuals, imposing preventive measures to hamper spreading of the contagious disease, e.g.: wearing face masks in the public spaces, quarantine and self-isolation (so called "lockdowns"), distant work at home instead of (so called "home offices"), home schooling of pupils, limited shopping times, limited access to public services such as public transport. Wearing face masks or respirators in work became compulsory for many employees, however it is very uncomfortable and subject of criticism. Use of digital technologies by public institution for contact tracing, for movement tracing, however enacted for limited purposes, became highly criticized by citizens in many countries as disruption of the privacy.

Because social contact enables unintentional spreading of COVID-19, many restrictions to limit free movement of people were adopted, that disturbed family connections, as well as sport, culture and other common activities. Also, many shops and service providers (such as hairdressers or florists) including social services had to be closed for certain periods. Limiting crossborder transit, shopping and service provision disrupted economic life, business and work opportunities. The various legislative measures to protect right to health had without no doubts impact on various social rights (such as access to general practitioners or supportive services for the elderly) and economic conditions of households, ability to pay bills and loans. Simultaneously, a series

3 Frell, (2015), Ústavno-právny vývoj poskytovania zdravotnej starostlivosti a d'alšie smerovanie zdravotníctva. In: 20 rokov Ústavy Slovenskej republiky - právne reflexive. [electronic document]. Bratislava: Univerzita Komenského, Právnická fakulta, 2015. ISBN 978-80-7160-379-5. p. 62-71 [CD-ROM]. 
of legislation was adopted to mitigate economic consequences of the pandemics, however, economic statistics in many countries confirm very alarming trends in unemployment etc. Protection of population health during the COVID-19 pandemics can be a legitimate reason for temporary and proportionate limitation of certain human rights. But, any restrictive legislative measures, however adopted for legitimate purposes, must take into consideration the side effects of legislation and carefully consider the proportionality principle during legislative process.

\section{Law and protection of population health}

Public health can be defined as science developing theory and practice of improving population health at societal or community level. Law can be seen as a tool of public health.

As pointed by Reynolds, public health laws typically have followed public health crises. During the Black Death of the midfourteenth century, European cities imposed a series of quarantine controls, arguably the first recognizable public health laws. However, the threat of visiting epidemics (for which quarantine controls were the logical response) was compounded by another set of threats to public health in the nineteenth century, when the inhabitants of newly emerging cities became the victims of chronic diseases caused by poverty, crowding, and an unhealthy environment. From this period of sanitary reform, our first recognizably modern public health laws emerged, whose basic structure remains in many countries to this day. ${ }^{4}$

${ }^{4}$ C. Reynolds, Legal Issues in Public Health. In International Encyclopedia of Public Health, Academic Press, 2008, Pages 45-56, ISBN 9780123739605, https:// doi.org/10.1016/B978-012373960-5.00128-3. 
Public health governance has developed a variety of legislative tools and mechanisms that allows to control not just physical, chemical, biological (such as viruses) hazards, but in some extent also social determinants of health. The social determinants of health can be defined as the social, economic, political, environmental and cultural factors that shape health. ${ }^{5}$ The regulation of health behavior of individuals and communities is one of big challenges of modern public health. Individual health behavior is recently considered by experts a key element in prevention of both contagious and non-contagious diseases and injuries.

One of main social functions of law is to be a tool of the social control, by imposing legal duties and enforcing the obligations. Law also should motivate people to follow the legal regulation, thus, the study of different forces that play active role in motivation of individual behaviour is important as well. Health law can be seen as a tool of control over special type of human behaviour, health behaviour. Thus, the factors that enable fulfilment of the social functions of health law, especially during the times of COVID-19 pandemics, should be studied thoroughly. To reach a high level of law efficiency, and lower the need for punishment, especially for the legislators can be very useful to be more familiar with theory of health behavior.

\section{Health behavior}

Recent reviews of research on health behavior change have shown that interventions based on theory or theoretical constructs are more effective than those not using theory.

${ }^{5}$ see further e.g. M. Kostičová, Social Determinats of Health and Disease. Pp.72 - 92 In: Kostičová M., et al.:Social Medicine, Bratislava: Comenius University in Bratislava, 2015. 
The field of health behavior research evolves for decades and recently a wide variety of theories and theoretical models are available in the literature. Ecological model helps to understand the human (health) behavior as result of interaction with the physical environment (barriers and opportunities) - e.g. whether organization of space allows to implement social distancing. The widely-used theoretical models of health behavior, as referenced in the literature of the field, are Social Cognitive Theory (SCT), The Transtheoretical Model/Stages of Change (TTM), the Health Belief Model (HBM), and the Theory of Planned Behavior (TPB). ${ }^{6}$

As pointed out by Noar and Zimmermann ${ }^{7}$ because of variability of types of health issues and health behaviors, no single theory is currently available to be appropriate for multiple health behaviors. The authors compared existing theories that are specific to certain behaviors and summarized:

- For behavior where illness avoidance and perceived threat are the most salient issues, a theory such as the HBM may be most appropriate.

- For behaviors that are more rational in nature and in which the intention-behavior link is strong, theories such as the TRA/TPB may be most appropriate.

- In addition, some suggest that stage models such as the TTM may be most applicable to deliberate behaviors

6 K. Glanz and B. K. Rimer, Theory at a Glance: A Guide for Health Promotion Practice. 2nd ed. National Cancer Institute, National Institutes of Health, U.S. Department of Health and Human Services. Washington, DC: NIH, (accessed 20 May 2020) available from: https://cancercontrol.cancer.gov/brp/research/theories_project/theory.pdf.

7 S. M. Noar, R. S. Zimmermann, Health Behavior Theory and cumulative knowledge regarding health behaviors: are we moving in the right direction? Health Education Research, Vol.20, No3, pp. 275-290, (accessed 5 Jun 2020) available from: https://doi.org/10.1093/her/cyg113 
(e.g. exercise) and less applicable to automatic behaviors that are simplistic (e.g. seatbelt use).

- Finally, a number of researchers point to the need for theoretical approaches to the maintenance of behavior change being distinct from initiation of behavior change. ${ }^{8}$

All of the above-mentioned theories consider different factors and variables to be important for self-regulation of individual health behavior. Normative beliefs, risk-related beliefs and emotional responses are related to the information and knowledge about the issue, but people also take into consideration how other people are behaving.

Slowing spreading of a contagious disease like COVID-19 is a legitimate public health goal and obligation of the state. Existing theories imply, that regulating health behavior with help of legislative measures is not easy. I tis important to note that there exist also different types of health behaviour, thus, the use of an appropriate theory to design interventions to reach health behavior change is not simple. Theories also suggest, that it is different to initiate a behavior change (such as self-isolation or social distancing), or to change simplistic automatic behavior (e.g. washing hands, using face masks in the public). For health behavior of an individual also matter factors as subjective perception of health risks, personal experience with some health problem, in general, risk-related beliefs and emotional responses. Health information are important, but they are filtered and subjectively evaluated by an individual, thus, individual perception of health risks, severity of

8 S. M. Noar, R. S. Zimmermann, Health Behavior Theory and cumulative knowledge regarding health behaviors: are we moving in the right direction? Health Education Research, Vol.20, No3, pp. 275-290, (accessed 5 Jun 2020) available from: https://doi.org/10.1093/her/cyg113. 
consequences etc. can be viewed differently by different people. And not always a given behavior is result of reasonable judgement of all available information and evaluation of pros and cons, sometimes it can be rather result of compliance with the shared public normative beliefs.

If the phenomenon of health hoaxes, disinformation related to health is studied, there can be observed the conflict of the right to health in one hand and right to freedom of opinion and expression in the other hand.

\section{Problem of misinformation}

Information and personal beliefs play important role in human behavior, but not just legal information can have impact on health behavior or legal behavior, ignorance or disobedience of law.

Since the start of COVID-19 pandemics, a massive wave of false or misleading information has hit Europe, such as misleading healthcare information, dangerous false claims, conspiracy theories but also consumer fraud. (European Commission, 10/06/2020) Advices not to follow public health measures are spread as well.

False, often dangerous, even lethal, advices have been posted, translated and spread among online communities in many countries. The problem is so giant that there already exist (besides country-specific myth-bustering, fact-checking and antihoax portals and projects) a new, specialist websitesrun by the WHO, some other international institution or e.g. Wikipedia just about misinformation related to the COVID-19 pandemic. $^{9}$

9 Misinformation related to the COVID-19 pandemic. (2020). Wikipedia. (accessed 21 Jun 2020) available from: https://en.wikipedia.org/wiki/Misinformation_related_to_the_COVID-19_pandemic. 
Why people all over the globe tend more and more to believe in conspiracy theories and misinformation about various topics, including health issues, is already a subject of the study of the international community of experts..$^{10} 11121314$

The current research suggests, that people over 65 share significantly more fake news than younger users do - and this is a population most vulnerable to COVID-19.

The social consequences of misinformation were studied as well. E.g., the European Parliament's Committee on Civil Liberties, Justice and Home Affairs (LIBE) requested a research study, assessing the impact of disinformation and strategic political propaganda disseminated through online social media sites. The study also examines effects on the functioning of the rule of law, democracy and fundamental rights in the EU and its Member States. Recommendations of experts on how to tackle this threat to human rights, democracy and the rule of law are formulated and published as a part of this study, too. ${ }^{15}$. According to this

10 see e.g. V. Kurincová Čavojová and I. Brezina, Why do we believe weird things? Recent trends in cognitive failures research in Slovakia. In 12th International Conference of Education, Research and Innovation (ICERI 2019). Seville, SPAIN : IATED, p. 2267-2276. ISBN 978-84-09-14755-7, 2019.

$11 \mathrm{H}$. Allcott, M. Gentzkow and Ch. Yu, Trends in the diffusion of misinformation on social media. Research \& Politics, Vol.6, No2, pp.1-8. https://doi. org/10.1177/2053168019848554, 2019.

12 S. Lewandowsky, U. K. Ecker, and J. Cook,2017.

${ }^{13}$ A. J. Berinsky, Rumors and Health Care Reform: Experiments in Political Misinformation. British Journal of Political Science, doi: 10.1017/S0007123415000186, 2015.

14 M. Balmas, When Fake News Becomes Real: Combined Exposure to Multiple News Sources and Political Attitudes of Inefficacy, Alienation, and Cynicism. Communication Research, Vol. 41. doi: 10.1177/0093650212453600, 2014.

15 J. Bayer, N. Bitiukova, P. Bard, J. Szakács, A. Alemanno and E. Uszkiewicz. (2019), Disinformation and Propaganda - Impact on the Functioning of the Rule of Law in the EU and its Member States. Brusel: European Union. 202p. ISBN 978-92846-4639-5. (accessed on 22 May 2020) Available at https://www.europarl.europa.eu/ thinktank. 
study „elements of disinformation and propaganda are that such information (i) is designed to be wholly or partly false, manipulated or misleading, or uses unethical persuasion techniques; (ii) regards an issue of public interest; (iii) has the intention to generate insecurity, hostility or polarisation, or attempts to disrupt democratic processes; (iv) and is disseminated and/or amplified through automated and aggressive techniques, such as social bots, artificial intelligence (Al), micro-targeting or paid human 'trolls', often used to boost public visibility." ${ }^{16}$.

The authors of the study found that impact of disinformation and propaganda on human rights is divided in two main categories: (1) impact on data protection, privacy, human dignity and autonomy; and (2) violation of the rights of freedom of expression and the right to seek and receive information.,, An open public discourse is one of the basic conditions of democracy, because this is how citizens can discuss their common matters, form political opinions and ultimately reach a political decision (e.g. voting in elections). To have a lively and rational discourse, media freedom, individual freedom of expression and the right to receive information are equally needed. Today's media environment gives individuals the chance to express their ideas at every possible instance - in this respect, the pluralism of ideas is overwhelming. This overwhelming volume of information makes navigation and access to trustworthy information a hard task. The (weakened) media system's earlier function of gatekeeping included filtering through professional editing, agenda defining and control by the political elite. These often-criticised checks also contributed to the stability of democratic systems.“ ${ }^{17}$. The authors highlight that „experimenting

\footnotetext{
16 Ibidem, p.9

17 Ibidem, p.11.
} 
with psychological reactions of masses of people should be regulated or ruled out, similar to biological experimenting..... Without regulatory intervention, business services and technology developers will take exploitation of human psychological traits and social engineering to new heights. Regulation should set the rules of the game, ideally with the cooperation of a wide range of stakeholders and global partners"18.

Disinformation related to COVID-19 had already proven social impact. People are not just sharing, forwarding disinformation, but also behave individually an organize for a collective action. Some individuals in Europe were engaging in criminal activities. "Outlandish or not, the online myth about the role of $5 \mathrm{G}$ in the epidemic has had real-life consequences all over Europe. According to the GSMA, as of 2 May 2020, there had been 67 arson attacks on $5 G$ towers in the UK, 22 in the Netherlands, 17 in France, three in Ireland, two in Cyprus, one each in Belgium, Italy and Sweden, and one suspected arson attack in Finland." 19. Some people organize or attended a so-called "COVID parties": "this is a party held by somebody diagnosed with the COVID virus, and the thought is that people get together to see if the virus is real and if anyone gets infected."Some deaths are already reported. ${ }^{20}$ Some people are refusing e.g. to wear face masks, claiming that COVID-19 is a myth. The current situation suggests, that people can easily deny expert recommendation not just in

18 Ibidem p.12.

19 J. Baker (2020), Europe's disinformation epidemic: Who's checking the facts? Heinrich Böll Stiftung. Posted 6 May 2020. (accessed 19 Jun 2020) available from: https://eu.boell.org/en/2020/05/06/disinfo-reaches-epidemic-proportions-andneeds-serious-eu-response

20 J. K. Elliott, I thought this was a hoax': Man, 30, dies after Texas 'COVID party'. Global News. Posted July 13, 2020. (accessed 20 July 2020) available from: https://globalnews.ca/news/7169518/coronavirus-covid-party-death-hoax/. 
the digital space, but also in real life, they engage in ignoring legally imposed measures and their individual health behavior puts in danger health and life of other people in their community. „Yet the "truths and counter-truths" debated online and offline have created a chaotic background noise that makes fact harder to distinguish from fiction. This is one of the most insidious ways in which disinformation works: the public can very quickly become fatigued with any sort of news and dismiss even responsible, factual, ethical reporting as "fake news." ${ }^{21}$.

As pointed out by Florek and Eroglu ${ }^{22}$, the current state of legal protection of human rights in cyberspace is not sufficient and relation between cyberspace and protection of human rights in this sphere should be further examined socially and legally.

Right to freedom of speech, right to personal opinion and its free expression and spreading comes to conflict with efforts of public health authorities and other institutions that protect right to health on the basis of evidence-based medicine.

Law reflects changes in society, at the same time law is an instrument of implementation of changes in a society, and a tool for their corrections. ${ }^{23}$ Legislators worldwide are due to COVID-19 pandemics facing a difficult task to manage very complex issues under time pressure, often in unpopular way, with high demand for correct content and technical qualities of the new legislation. And in case of interference of new regulations with human rights standards, there is demand for being aware of proportionality.

21 J. Baker, op. cit.

22 I. B. Lorek, S. E. Eroglu, The Need for Protection of Human Rights in Cyberspace. Journal of Modern Science, 42(3), 27-36. https://doi.org/10.13166/ jms/112765, 2019.

23 S. Capíková, Between Order and Chaos: Law in the Period of Post-Communist Transformation in Slovakia. Sociologický časopis /Czech Sociological Review, 41(4), 617-640. doi: 10.13060/00380288.2005.41.4, 2005, p.618. 
As pointed by J. Cianciardo, the principle of proportionality is applied by constitutional courts in both civil law and common law systems and also by the European Court of Human Rights, the Inter-American Court of Human Rights and the European Court of Justice as a procedure that aims to guarantee the full respect of human rights (or fundamental rights) by the state: „The principle of proportionality prescribes that all statutes that affect human rights should be proportionate or reasonable. The analysis of proportionality is made up of three sub-principles: adequacy, necessity, and proportionality stricto sensu. ${ }^{\text {"24 }}$

In any debate about human rights and their interrelations and possible conflicts and limitation of human rights especially during extraordinary situation due to COVID-19, there is to consider obligations of those, whose rights are protected. The Universal Declaration of Human Rights ${ }^{25}$ in its Article 29 states: „(1) Everyone has duties to the community in which alone the free and full development of his personality is possible. (2) In the exercise of his rights and freedoms, everyone shall be subject only to such limitations as are determined by law solely for the purpose of securing due recognition and respect for the rights and freedoms of others and of meeting the just requirements of morality, public order and the general welfare in a democratic society.(3) These rights and freedoms may in no case be exercised contrary to the purposes and principles of the United Nations."

$24 \mathrm{~J}$ Cinciardo, The Principle of Proportionality: The Challenges of Human Rights, Journal of Civil Law Studies, Vol3, No1. (accessed on 15 May 2020) Available at: https://digitalcommons.law.Isu.edu/jcls/vol3/iss1/11, 2010, p.179.

25 Universal Declaration of Human Rights, United Nations. (accessed 21 Jun 2020) available from: https://www.un.org/en/universal-declaration-human-rights/, 1948. 
Spreading of misinformation is a form of collective behavior, very difficult to control by means of law, especially in the cyberspace/digital space. Many countries worldwide are avoiding to restrict freedom of speech rigorously and to limit exercise of the right to freedom of opinion and expression, taking into consideration the possible risk that restriction or criminalization may be applied arbitrarily and can be potentially abused by the state representatives against its political opponents or for critical opinions against state bodies. E.g., Hungary in March 2020 adopted as legal response to the COVID-19 pandemics also an amendment to the Penal Code focusing scaremongering during a special (emergency) legal order. A person who "during the period of special legal order and in front of a large audience, states or disseminates any untrue fact or any misrepresented true fact that is capable of hindering or preventing the efficiency of protection, is guilty of a felony," the law states. Almost immediately, an appeal submitted to the court claimed the law carrying a five-year prison sentence, restricts freedom of speech. The Constitutional Court of Hungary stated in Jun 2020 that it was necessary and proportionate to put limits on speech if there was an overriding social interest in doing so. The court noted that the disputed parts of the Penal Code prohibit "communication of knowingly false or distorted facts to the general public" only if the authorities are thereby hindered in their ability to implement protective measures during an emergency. The ban, the court added, does not apply to critical opinions. ${ }^{26}$ Thus, sharing misinformation e.g. via so called "chain e-mails" cannot be criminalized per se, but, how often can

${ }^{26}$ P. CSERESNYÉS, Constitutional Court: March Law on Scare-Mongering Not Unconstitutional. In: Hungary Today. Published on 17 Jun 2020. (accessed 21 Jun 2020) available from: https://hungarytoday.hu/constitutional-court-march-law-on-scare-mongering-not-unconstitutional/, 2020. 
be possible to identify the person who originally and intentionally formulated the false information and has started the chain?

So, in democratic societies, a lot of effort is shown for socalled myth-bustering, mapping of disinformation and publishing corrections. That is costly for human and financial resources.

We should be aware of the importance of communication in democratic societies, as pointed out by $\mathrm{M}$. Indellicato : „The use of language is very important because, used correctly and ethically, it can lead to an intersubjective action that makes possible positive experiences with which men constitute the social and political community according to an understanding that does not cancel differences and diversity. “27

\section{Conclusion}

"Public health law theory enables a nuanced understanding of the role of government in creating the conditions for people to be healthy, the reasonable limits that governments may place on personal freedom to promote the health of the population. It provides a framework in which to understand the legal basis for the enactment and operation of public health laws. Legal issues in public health, including those that drive litigation, occur when misalignments between legislation, regulation, and policy cause legislators or their delegates to misuse (either overstep or underuse/neglect) their powers." 28

27 M. Indellicato, Ethics of communicative action and human rights in Habermas. Journal of Modern Science, 43(4):75-99. (accessed 10 Jun 2020) available from: https://doi.org/10.13166/jms/117988, 2019, p.94.

28 S. P. Kowal, T. Bubela, Legal Issues in Public Health. In: Stella R. Quah (ed.): International Encyclopedia of Public Health (Second Edition), Academic Press, 2017, Pages 384-390, ISBN 9780128037089, https://doi.org/10.1016/B978-0-12803678-5.00250-2. 
COVID-19 pandemics highlighted the importance of information in the current societies. Itis widely accepted that communication in the public sphere is a vital component of democracy. However, spreading of misinformation, especially related to health and prevention, seems to be as dangerous as the biological virus. But how to protect health, people and society from negative impact of both virus and harmful misinformation? The paper presented is an attempt to outline the extent of the problem.

However, experts warn that freedom to access true information can be considered as human rights violation ${ }^{29}$. Short look into conversations in the public content of various electronic/ digital communication channels shows, that misinformation (often denying also common-sense measures such as hand hygiene) are creating background of negative attitudes to expert knowledge, law and legal measures. However, more research is needed to confirm the linkage between efficiency of public health law and disinformation. The need for further research in determinants of law efficiency in field of public health, such as economic analysis of law, also can be promising. Deeper collaboration between health jurisprudence, constitutional jurisprudence, sociology of law, ethics and public health science could be supported. The problem is very complex and easy solutions are not available. More legal and multidisciplinary research is needed to define the boundaries of exercise of human rights and general welfare, regulation of digital platforms - sharing of unwanted or misleading content, aggressive online advertising of quackery health products based on business of digital providers with personal data such as personal preferences and traits, etc.

29 J. Bayer, op. cit., p.74 


\section{References:}

ALLCOTT H., GENTZKOW M. and YU Ch., Trends in the diffusion of misinformation on social media. Research \& Politics, Vol. 6, No 2, 2019, pp.1-8. https://doi.org/10.1177/2053168019848554

BAKER J., Europe's disinformation epidemic: Who's checking the facts? Heinrich Böll Stiftung. Posted 6 May 2020. (accessed 19 Jun 2020) available from: https://eu.boell.org/en/2020/05/06/disinforeaches-epidemic-proportions-and-needs-serious-eu-response

BALMAS, M. (2014), When Fake News Becomes Real: Combined Exposure to Multiple News Sources and Political Attitudes of Inefficacy, Alienation, and Cynicism. Communication Research, Vol. 41. doi: 10.1177/0093650212453600.

BAYER J., BITIUKOVA N., BARD P., SZAKÁCS J., ALEMANNO A. AND USZKIEWICZ E. (2019), Disinformation and Propaganda - Impact on the Functioning of the Rule of Law in the EU and its Member States. Brusel: European Union. 202p. ISBN 978-92-846-46395. (accessed on 22 May 2020) Available at https://www.europarl. europa.eu/thinktank

BERINSKY, A.J. (2015), Rumors and Health Care Reform: Experiments in Political Misinformation. British Journal of Political Science, doi: 10.1017/S0007123415000186.

CAPÍKOVÁ, S. (2005), Between Order and Chaos: Law in the Period of Post-Communist Transformation in Slovakia. Sociologický časopis /Czech Sociological Review, 41(4), 617-640. doi: 10.13060/00380288.2005.41.4

CIANCIARDO J. (2010), The Principle of Proportionality: The Challenges of Human Rights, Journal of Civil Law Studies, Vol3, No1. (accessed on 15 May 2020) Available at: https://digitalcommons.law.Isu.edu/ jcls/vol3/iss $1 / 11$

CSERESNYÉS P. (2020), Constitutional Court: March Law on ScareMongering Not Unconstitutional. In: Hungary Today. Published on 17 Jun 2020. (accessed 21 Jun 2020) available from: https:// hungarytoday.hu/constitutional-court-march-law-on-scaremongering-not-unconstitutional/ 
ELLIOTT, J.K. (2020), 'I thought this was a hoax': Man, 30, dies after Texas 'COVID party'. Global News. Posted July 13, 2020. (accessed 20 July 2020) available from: https://globalnews.ca/news/7169518/ coronavirus-covid-party-death-hoax/

FLOREK, I. B., EROGLU, S. E. (2019), The Need for Protection of Human Rights in Cyberspace. Journal of Modern Science, 42(3), 27-36. https://doi.org/10.13166/jms/112765

FREEL, (2015), Ústavno-právny vývoj poskytovania zdravotnej starostlivosti a d’alšie smerovanie zdravotníctva. In: 20 rokov Ústavy Slovenskej republiky - právne reflexive. [electronic document]. Bratislava: Univerzita Komenského, Právnická fakulta, 2015. ISBN 978-80-7160-379-5. p. 62-71 [CD-ROM].

GLANZ, K., RIMER, B.K. (2005), Theory at a Glance: A Guide for Health Promotion Practice. 2nd ed. National Cancer Institute, National Institutes of Health, U.S. Department of Health and Human Services. Washington, DC: NIH, (accessed 20 May 2020) available from: https://cancercontrol.cancer.gov/brp/research/theories_project/ theory.pdf

INDELLICATO, M.(2019), Ethics of communicative action and human rights in Habermas. Journal of Modern Science, 43(4):75-99. (accessed 10 Jun 2020) available from: https://doi.org/10.13166/jms/117988

KOSTIČOVÁ M. (2015), Social Determinats of Health and Disease. Pp.72 - 92 In: Kostičová M., et al.:Social Medicine, Bratislava: Comenius University in Bratislava, 2015.

KOWAL, S.P., BUBELA, T. (2017), Legal Issues in Public Health. In: Stella R. Quah (ed.): International Encyclopedia of Public Health (Second Edition), Academic Press, 2017, Pages 384-390, ISBN 9780128037089, https://doi.org/10.1016/B978-0-12-8036785.00250-2.

KURINCOVÁ ČAVOJOVÁ, V. - BREZINA, I. (2019), Why do we believe weird things? Recent trends in cognitive failures research in Slovakia. In 12th International Conference of Education, Research and Innovation (ICERI 2019). Seville, SPAIN : IATED, p. 2267-2276. ISBN 978-84-09-14755-7. 
LEWANDOWSKY, S., ECKER, U. K., and COOK, J. (2017), Beyond misinformation: Understanding and coping with the "post-truth" era. Journal of applied research in memory and cognition, 6(4), 353-369. Accessed from: doi:10.1016/j.jarmac.2017.07.008

MANN, J.M. (1997), Medicine and Public Health, Ethics and Human Rights. In: Hastings Center Report, 27, pp. 6-13. (accessed 10 Jun 2020) available from: doi: $10.2307 / 3528660$

Misinformation related to the COVID-19 pandemic. (2020). Wikipedia. (accessed 21 Jun 2020) available from: https://en.wikipedia.org/ wiki/Misinformation_related_to_the_COVID-19_pandemic

NOAR, S.M., ZIMMERMAN, R.S. (2005), Health Behavior Theory and cumulative knowledge regarding health behaviors: are we moving in the right direction? Health Education Research, Vol.20, No3, pp. 275-290, (accessed 5 Jun 2020) available from: https://doi. org/10.1093/her/cyg113

REYNOLDS, C.(2008), Legal Issues in Public Health. In International Encyclopedia of Public Health, Academic Press, 2008, Pages 45-56, ISBN 9780123739605, https://doi.org/10.1016/B978-0123739605.00128-3.

Universal Declaration of Human Rights (1948), United Nations. (accessed 21 Jun 2020) available from: https://www.un.org/en/universaldeclaration-human-rights/ 